\title{
Bioactive compounds in sweet rowanberry fruits of interspecific Rowan crosses
}

Jiri Mlcek1*, Otakar Rop², Tünde Jurikova ${ }^{3}$, Jiri Sochor ${ }^{4}$, Miroslav Fisera ${ }^{1}$, Stefan Balla ${ }^{3}$, Mojmir Baron ${ }^{4}$, Jan Hrabe ${ }^{2}$

${ }^{1}$ Department of Food Chemistry and Analysis, Faculty of Technology, Tomas Bata University in Zlin, CZ-762 72 Zlin, Czech Republic

${ }^{2}$ Department of Gastronomy, College of Business and Hotel Management, CZ-625 00 Brno, Czech Republic

${ }^{3}$ Department of Natural and Informatics Sciences, Faculty of Central European Studies, Constantine the Philosopher University in Nitra, SK-949 74 Nitra, Slovakia

${ }^{4}$ Department of Viticulture and Enology, Faculty of Horticulturae, Mendel University in Brno, CZ-691 44 Lednice, Czech Republic

Received 19 August 2013; Accepted 16 February 2014

Abstract: Sweet rowanberries originated by the crossbreeding of wild rowanberries with other fruit species such as apples, medlars or black chokeberries. They are highly resistant to cold climate. In contrast with wild rowanberries, they have sweet mild taste and show less parasorbic acid toxicity, which can be eliminated, when the consumption is excessive, by heating. The objective of the work was to determine selected antioxidant properties in 6 cultivars. The analyses showed that the contents of total phenolics, total flavonoids and ascorbic acid were high. Similarly, antioxidant capacity (6.58-9.62 $\mathrm{g}$ of ascorbic acid equivalents $\left.\mathrm{kg}^{-1}\right) \mathrm{was}$ also high. The work brings novel data, in particular, when comparing the cultivars; moreover, results regarding reactive oxygen and nitrogen species scavenging activity in sweet rowanberries are being published for the first time. The sweet rowanberry extracts $(10 \%)$ showed inhibitory ability on hydroxyl radical (16.12-24.73\%), superoxide anion (26.74-34.02\%), nitric oxide (24.75-31.39\%), and lipid peroxidation (7.93-13.12\%). The values obtained are even many times higher than those found in common commercial fruit species like apples. Therefore, sweet rowanberries appear to be a promising fruit species for human nutrition, especially due to their high content of bioactive substances and ease of cultivation in worse climatic and soil conditions.

Keywords: Interspecific crosses of Rowan - Sorbus aucuparia - Phenolics - Flavonoids - Antioxidant capacity • Ascorbic acid - Reactive oxygen species • Reactive nitrogen species

(C) Versita Sp. z 0.0 .

\section{Introduction}

The rowan tree (Sorbus aucuparia L.) belongs to the Rosaceae family and it grows in the temperate zone, especially in its northern parts with a common occurrence in nature there [1,2]. This tree species occurs on roadsides or in parks. It has are orange-red berries ranging from 0.5 to $2 \mathrm{~cm}$ in diameter [3], having a bitter taste, and the fresh fruit is slightly toxic due to the parasorbic acid and hydrogen cyanide content [4]. The toxicity is destroyed by heating, drying or standing in a weak vinegar solution [5]. The first sweet rowanberries originated from a natural breeding process and they were found in Northern Moravia, the area of the current Czech Republic, in the second half of the 19th century. They were named Moravian rowans, in Latin labelled as 
Sorbus aucuparia var. dulcis Dieck. or moravica Zeng. [6]. Compared with rowanberries, sweet rowanberries have a mild taste and a lower amount of parasorbic acid.

In an attempt to grow new fruit species as well as cultivars which would be resistant to low temperature and adapted to a shorter vegetation period, a crossbreeding program of fruit woody plants has been conducted. First, at the beginning of the 20th century, Michurin in Russia $[7,8]$ carried out research with the attention being given to the genus Sorbus crossed with hawthorn (Crataegus), medlar (Mespilus), black chokeberry (Aronia), apple (Malus), and pear (Pyrus). In the crosses, considerable frost resistance, fertility needed and required characteristics of fruit were accomplished so that the crosses could be suitable for consumption and further processing such as making fruit compotes or for the production of liquors, wines or spirits [3].

In these crosses, high antioxidant capacity is caused, in particular, by the content of phenolics. The rowanberries cultivars and hybrids studied by Hukkanen et al. (Burka, Dessertnaja, Eliit, Granatnaja, Kubovaja, Rosina, Rubinovaja, Titan, and Zholtaja) displayed high antioxidant capacity correlated to phenolic contents. Moreover, statistically significant differences in antioxidant capacity of different cultivars are given by origin of assayed simplex [9]. It seems that flavonoids as one of the group of phenolic compounds are of key importance in relation to antioxidant capacity in rowanberries [10]. Their antioxidant capacity affects reactive oxygen species (ROS) and reactive nitrogen species (RNS). ROS and RNS are generated in metabolism of a living organism [11,12]. Excessive amounts of these reactive species may be harmful since they can initiate biomolecular oxidations which lead to cell injury due to the mutual reaction to form peroxonitrite [13]. ROS and RNS are implicated in the pathophysiology of diseases, such as cancer, rheumatoid arthritis, cirrhosis and arteriosclerosis as well as in degenerative processes associated with ageing [14]. Lipid peroxidation is often caused by ROS and RNS as an oxidative alteration of polyunsaturated fatty acids. In a biological system, lipid peroxidation generates a number of degradation products and it is found to be an important cause of cell membrane destruction [15]. Kylli et al. (2010) found that cultivation of rowanberries resulted in increased anthocyanin content, too [16].

The main objective of this study was to determine the following antioxidant properties of rowanberries: the total phenolic content (TPC), total antioxidant capacity (TAC), total flavonoid content (TFC), and ascorbic acid content (AAC). Scavenging activities of $10 \%$ methanolic extracts of six sweet rowanberry cultivars fruits on nitric oxide (NO), superoxide anion (SA), hydroxyl radical (HA) and lipid peroxidation (LP) were indicated, too; results of the above analyses of rowanberry scavenging activity on NO, SA, HA and LP have not been reported in literature yet.

\section{Experimental procedures}

\subsection{Plant material}

Fruits were harvested in an experimental gene-fund orchard of Mendel University in Brno (MUB). This orchard is situated in the area of the village Zabcice, approximately $20 \mathrm{~km}$ southwards from Brno, the Czech Republic. The average annual temperature and a fiftyyear average sum of precipitation are $9^{\circ} \mathrm{C}$ (during the growing season $15.6^{\circ} \mathrm{C}$ ) and $553 \mathrm{~mm}$ (during the growing season $356 \mathrm{~mm}$ ), respectively. Soils are classified as gleyed alluvial soils developed on the Holocene calciferous sediments with a marked accumulation of organic compounds. Concerning the texture, the topsoil is loamy and the subsoil clayey-loamy [17].

Fruits in consume ripeness from three trees of each cultivar studied were harvested in the course of August 2011 and 2012. Fifty randomly chosen fruits from each tree were used for analyses (i.e. altogether 150 per each cultivar). The fruits of particular cultivars were processed immediately after the harvest (not later than within two days). Harvested fruits were puréed in a mixer and the average sample was obtained by dividing the purée into quarters. Each parameter was measured in five replications.

The following cultivars were used: Burka, Dezertnaya, Granatina, Granatnaya, Likernaya, Titanovaya (see Table 1 for more details). For comparison, the wild rowanberries were used $[3,10]$.

\subsection{Extraction procedure}

The extraction was performed according to the method described by Barros et al. (2007), using the following procedure: $10 \mathrm{~g}$ of a fresh sample were homogenized for $10 \mathrm{sec}$ in $100 \mathrm{ml}$ of methanol in a SJ500 laboratory grinder (MEZOS, Hradec Kralove, the Czech Republic). The resulting paste was placed into Erlenmeyer flasks $(120 \mathrm{ml})$ and let to stand in a water bath with the temperature of $+25^{\circ} \mathrm{C}$ for a period of $24 \mathrm{~h}$. After the extraction, the content of the flask was filtrated using a Filtrapak No. 390 paper (Petr Lukes, Uhersky Brod, the Czech Republic) and stored at $+4^{\circ} \mathrm{C}$ for further use [18].

\subsection{Total phenolic content assay}

To measure total contents of phenolic substances, $0.5 \mathrm{ml}$ of the sample was taken and diluted with water 


\begin{tabular}{c|cc}
\hline Cultivar & Breeding background & Description \\
\hline \hline Wild rowanberry & Sorbus aucuparia & medium sized berry, red colour \\
Burka & Sorbus aucuparia x [Sorbus aria x Aronia arbutifolia] & medium sized berry, reddish brown colour \\
Dezertnaya & Sorbus aucuparia x Aronia melanocarpa x Mespilus & Rermanica \\
Granatina & Sorbus aucuparia x Crataegus sanguinea x Crataegus & medium sized berry, red colour \\
Granatnaya & laevigata & large sized berry, dark red colour \\
Likernaya & Sorbus aucuparia x Crataegus sanguinea & large sized berry, dark red colour \\
Titanovaya & Sorbus aucuparia x Aronia melanocarpa & medium sized berry, light red colour \\
\hline
\end{tabular}

Table 1. Description of Sweet Rowanberry Cultivars $[3,10]$.

in a $50-\mathrm{ml}$ volumetric flask. Thereafter, $2.5 \mathrm{ml}$ of FolinCiocalteau reagent and $7.5 \mathrm{ml}$ of a $20 \%$ solution of sodium carbonate were added. Using a LIBRA S6 spectrophotometer (Biochrom Ltd., Cambridge, the UK), the resulting absorbance was measured at the wavelength of $765 \mathrm{~nm}$ against a blind sample as the zero reference solution. In calculating the content of phenolic substances, the results were expressed as $\mathrm{g}$ of gallic acid (GAE) $\mathrm{kg}^{-1}$ of fresh mass (FM) [19].

\subsection{Antioxidant capacity by the DPPH test assay}

The DPPH (2,2-Diphenyl-1-picrylhydrazyl) assay was conducted according to the method of Thaipong et al. (2006) [20]. This test is based on the reduction of $\mathrm{DPPH}^{*}$. In its radical form, DPPH* absorbs light at $515 \mathrm{~nm}$, but upon reduction by an antioxidant or radical species, there is no absorption at that wavelength.

The stock solution was prepared by dissolving $24 \mathrm{mg}$ of DPPH with $100 \mathrm{ml}$ of methanol and then stored at $-20^{\circ} \mathrm{C}$ until needed. The working solution was obtained by mixing $10 \mathrm{ml}$ of the stock solution with $45 \mathrm{ml}$ of methanol to get the absorbance of $1.1 \pm 0.02$ units at $515 \mathrm{~nm}$ using a LIBRA S6 spectrophotometer (Biochrom Ltd., Cambridge, the UK). Fruit extracts $(150 \mu \mathrm{l})$ were allowed to react with $2,850 \mu$ l of the DPPH solution for 24 hours in the dark. Then the absorbance at $515 \mathrm{~nm}$ was taken.

The values of absorbance were converted using a calibration curve of the standard and expressed in ascorbic acid equivalents (AAE) [21].

\subsection{Total flavonoid content assay}

The total flavonoid content was determined following Singleton et al. (1999) [22]. Into a $10 \mathrm{ml}$ Eppendorf tube, $0.3 \mathrm{ml}$ of the fruit extract, $3.4 \mathrm{ml}$ of $30 \%$ ethanol, $0.15 \mathrm{ml}$ of $\mathrm{NaNO}_{2}\left(\mathrm{c}=0.5 \mathrm{~mol} \mathrm{dm}{ }^{-3}\right)$ and $0.15 \mathrm{~nm}$ of $\mathrm{AlCl}_{3} \cdot 6 \mathrm{H}_{2} \mathrm{O}$ (c $=0.3 \mathrm{~mol} \mathrm{dm}^{-3}$ ) were put and mixed. After $5 \mathrm{~min}, 1 \mathrm{ml}$ of $\mathrm{NaOH}\left(\mathrm{c}=1 \mathrm{~mol} \mathrm{dm}^{-3}\right)$ was added, and the absorbance of the mixture was measured at the wavelength of $506 \mathrm{~nm}$ using a LIBRA S6 spectrophotometer (Biochrom Ltd., Cambridge, the UK). The total flavonoid concentration was calculated from a calibration curve using rutin as the standard. The results were expressed as $\mathrm{g}$ of rutin $\mathrm{kg}^{-1} \mathrm{FM}$.

\subsection{Ascorbic acid content assay}

The determination of ascorbic acid content (AAC) was done according to a modified method by Miki (1981) using $5 \mathrm{~g}$ of the homogenized fruit weighed in an Erlenmeyer flask and by adding $25 \mathrm{ml}$ of extractant compounded from methanol: $\mathrm{H}_{2} \mathrm{O}: \mathrm{H}_{3} \mathrm{PO}_{4}$ in the ratio of $99: 0.5: 0.5$ [23]. The flask with the samples was placed into a water bath with the temperature of $+25^{\circ} \mathrm{C}$ and there the samples were extracted for $15 \mathrm{~min}$. To keep out the samples of daylight, the flask was covered with aluminium foil during the preparation. After the extraction, the content of the flask was filtrated using a Filtrapak No. 390 paper (Petr Lukes, Uhersky Brod, the Czech Republic). Before injection, the filtrate prepared in this way was diluted in ration of extractant and filtrated again through a membrane Nylon $0.45 \mu \mathrm{m}$ filter (Petr Lukes, Uhersky Brod, the Czech Republic). The instrument used for ascorbic acid analysis consisted of a solvent delivery pump (Model 582, ESA Inc., Chelmsford, the USA), a guard cell (Model 5010A, with a working electrode potential $\mathrm{K} 1=600 \mathrm{mV}, \mathrm{K} 2=650 \mathrm{mV}$, ESA Inc., Chelmsford, the USA), a chromatographic Supelcosil LC8 Model column $(150.0 \times 4.6 \mathrm{~mm}), 5 \mu \mathrm{m}$ particle size and a Coulochem III electrochemical detector (ESA Inc., Chelmsford, the USA). The chromatographic conditions used were constant: $30^{\circ} \mathrm{C}$; a mobile phase (filtrated through a Nylon, $0.2 \mu \mathrm{m}$ filter) comprising methanol, $\mathrm{H}_{2} \mathrm{O}$, and $\mathrm{H}_{3} \mathrm{PO}_{4}$ in the proportion of $99: 0.5: 0.5$ respectively; isocratic elution; and the flow rate of the mobile phase at $1.1 \mathrm{ml} \mathrm{min}^{-1}$. The content of ascorbic acid was calculated as $\mathrm{g} \mathrm{kg}^{-1}$ of fresh mass. 


\subsection{Reactive oxygen species scavenging activity assay}

For the measurement of ROS, RNS, and LP, a $10 \%$ fruit extract in the phosphate buffer $\left(c=50 \mathrm{mmol} \mathrm{L}^{-1}\right.$, $\mathrm{pH}$ 7.0) was prepared. The hydroxyl radical scavenging activity was assayed according to Ghiselli et al. (1998) [24]. One $\mathrm{ml}$ of the extract was mixed with $0.8 \mathrm{ml}$ of a reaction buffer (phosphate buffer, $20 \mathrm{mmol} \mathrm{L}^{-1}, \mathrm{pH} 7.4$; deoxyribose, $1.75 \mu \mathrm{mol} \mathrm{L}^{-1}$; iron ammonium sulphate, 0.1

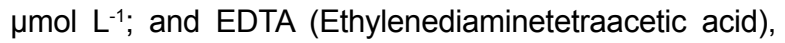
$\left.0.1 \mu \mathrm{mol} \mathrm{L}^{-1}\right) .0 .1 \mathrm{ml}$ of $\mathrm{H}_{2} \mathrm{O}_{2}\left(0.01 \mathrm{~mol} \mathrm{~L}^{-1}\right)$ was then added to the reaction solution. The solution was incubated for $10 \mathrm{~min}$ at $+37^{\circ} \mathrm{C}$ prior to the addition of $0.5 \mathrm{ml}$ of $1 \%$ thiobarbituric acid and $1 \mathrm{ml}$ of $2.8 \%$ trichloracetic acid. The mixture was boiled for $10 \mathrm{~min}$ and cooled rapidly. The absorbance of the mixture was measured at $532 \mathrm{~nm}$ with a LIBRA S6 apparatus (Biochrom Ltd., Cambridge, the UK).

The superoxide anion scavenging activity was conducted according to the method based on the reduction of cytochrome $c$ (Beissenhirtz et al., 2004) [25]. One $\mathrm{ml}$ of the extract was mixed with $1 \mathrm{ml}$ of the solution containing xanthine oxidase $\left(0.07 \mathrm{U} \mathrm{ml}^{-1}\right)$, xanthine $(100 \mu \mathrm{mol} \mathrm{IL}-1)$ and cytochrome $c\left(50 \mu \mathrm{mol} \mathrm{L}^{-1}\right)$. After incubation at $+20^{\circ} \mathrm{C}$ for $3 \mathrm{~min}$, the absorbance at $550 \mathrm{~nm}$ was determined.

All tests were performed in triplicate. The scavenging activities of hydroxyl radical and superoxide anion were calculated as follows:

$$
\text { Scavenging activity }(\%)=\left(A_{0}-A_{1} / A_{0}\right) \times 100 \%
$$

where $A_{0}$ is the absorbance of the control solution (without the sample) and $A_{1}$ is the absorbance of the mixture containing the sample.

\subsection{Reactive nitrogen species scavenging activity assay}

The assay of nitric oxide scavenging activity was performed according to the method by Green et al. (1982) when $1 \mathrm{ml}$ of the extract was mixed with $1 \mathrm{ml}$ of the reaction solution containing sodium nitroprusside (10 $\left.\mathrm{mmol} \mathrm{L}^{-1}\right)$ in the phosphate buffer $\left(20 \mathrm{mmol} \mathrm{L}^{-1}, \mathrm{pH}\right.$ 7.4). The incubation at $+37^{\circ} \mathrm{C}$ for $1 \mathrm{~h}$ followed and $0.5 \mathrm{ml}$ of the aliquot was then mixed with $0.5 \mathrm{ml}$ of Griess reagent. The absorbance was measured at $540 \mathrm{~nm}$ [26].

All tests were performed in triplicate. The scavenging activity of nitric oxide was calculated as follows:

\section{Scavenging activity $(\%)=\left(A_{0}-A_{1} / A_{0}\right) \times 100 \%$}

where $A_{0}$ is the absorbance of the control solution (without the sample) and $A_{1}$ is the absorbance of the mixture containing the sample.

\subsection{Lipid peroxidation inhibition activity}

The inhibition of lipid peroxidation was assayed by using $5 \mu \mathrm{g}$ of the rat liver tissue homogenized in $20 \mathrm{ml}$ of Tris- $\mathrm{HCl}$ buffer $\left(50 \mathrm{mmol} \mathrm{L}^{-1}, \mathrm{pH} 7.6\right)$. The amount of $0.1 \mathrm{ml}$ of the liver homogenate was incubated with the sample $(0.2 \mathrm{ml}$ of a $10 \%$ extract $), 0.1 \mathrm{ml}$ of $\mathrm{KCl}$ $\left(30 \mathrm{mmol} \mathrm{L}^{-1}\right), 0.1 \mathrm{ml}$ of $\mathrm{FeSO}_{4}\left(0.16 \mathrm{mmol} \mathrm{L}^{-1}\right)$ and $0.1 \mathrm{ml}$ of ascorbic acid $\left(0.06 \mathrm{mmol} \mathrm{L}^{-1}\right)$ at $+37^{\circ} \mathrm{C}$ for $1 \mathrm{~h}$. Thereafter, $1 \mathrm{ml}$ of $1 \%$ thiobarbituric acid (TBA) and $1 \mathrm{ml}$ of $15 \%$ trichloracetic acid were added. The final solution was heated at $+100^{\circ} \mathrm{C}$ in a boiling water bath for $15 \mathrm{~min}$, cooled with ice for $10 \mathrm{~min}$, and then centrifuged at 5,000 r.p.m. for 10 min using a MPW-54 apparatus (Unimed, Prague, the Czech Republic). The absorbance of the supernatant was measured at $532 \mathrm{~nm}$, using a LIBRA S6 spectrophotometer (Biochrom Ltd., Cambridge, UK). The blank was prepared by substituting the Tris-HCl buffer (50 mmol L-1, $\mathrm{pH} 7.6)$ for the sample. The per cent inhibition of the formation of TBA-reactive substances was calculated as:

$$
\text { Inhibition activity }(\%)=\left(A_{0}-A_{1} / A_{0}\right) \times 100 \%
$$

where $A_{0}$ is the absorbance of the control solution (without the sample) and $A_{1}$ is the absorbance of the mixture containing the sample [27].

\subsection{Statistical Analysis}

The data obtained were analyzed statistically by the analysis of variance (ANOVA) and Tukey's multiple range test for comparison of means. Correlation functions were calculated using the Unistat, v. 5.1 statistical package and Office Excel® Microsoft 2010.

\section{Results and discussion}

The results of chemical analyses are given in Tables 2 and 3. The outcomes of statistical evaluation are shown in Tables 4 and 5. All the results are expressed as a two-year average; there were no statistically significant differences between individual years.

Regarding the total content of polyphenolic compounds in wild rowanberries, on average 4.27 grams of gallic acid/kg FM was found, which is generally common in these wild berries [28], or it is even slightly more than reported in the Mikulic-Petkovsek et al. (2012) work with respect to this fruit species [29]. Bravo [30] noticed similar contents. In addition, Kampuss et al. (2008) observed the same values, in some years the content of polyphenols even doubled [8]. The total phenolic content can vary greatly among the sweet rowanberry cultivars ranging from 5.5 to $10.14 \mathrm{~g} \mathrm{~kg}^{-1} \mathrm{GAE}$ of fresh weight 


\begin{tabular}{c|cccc}
\hline Cultivar & Total phenolic content & Antioxidant capacity & Total flavonoid content & Ascorbic acid \\
\hline \hline Wild rowanberry & $4.27 \pm 0.59^{\mathrm{a}}$ & $6.73 \pm 0.35^{\mathrm{a}}$ & $3.11 \pm 0.27^{\mathrm{a}}$ & $1.19 \pm 0.21^{\mathrm{a}}$ \\
Burka & $7.89 \pm 0.47^{\mathrm{b}}$ & $8.29 \pm 0.40^{\mathrm{b}}$ & $4.89 \pm 0.34^{\mathrm{b}}$ & $1.63 \pm 0.19^{\mathrm{b}}$ \\
Dezertnaya & $6.52 \pm 0.51^{\mathrm{c}}$ & $7.96 \pm 0.59^{\mathrm{b}}$ & $4.18 \pm 0.36^{\mathrm{b}}$ & $2.18 \pm 0.23^{\mathrm{c}}$ \\
Granatina & $8.11 \pm 0.71^{\mathrm{b}}$ & $9.62 \pm 0.52^{\mathrm{c}}$ & $5.65 \pm 0.25^{\mathrm{c}}$ & $2.10 \pm 0.22^{\mathrm{c}}$ \\
Granatnaya & $8.19 \pm 0.56^{\mathrm{b}}$ & $9.50 \pm 0.57^{\mathrm{c}}$ & $5.35 \pm 0.27^{\mathrm{bc}}$ & $2.15 \pm 0.20^{\mathrm{c}}$ \\
Likernaya & $4.35 \pm 0.60^{\mathrm{a}}$ & $6.58 \pm 0.37^{\mathrm{a}}$ & $3.37 \pm 0.20^{\mathrm{a}}$ & $1.54 \pm 0.20^{\mathrm{b}}$ \\
Titanovaya & $6.28 \pm 0.45^{\mathrm{c}}$ & $7.39 \pm 0.39^{\mathrm{ab}}$ & $4.70 \pm 0.25^{\mathrm{b}}$ & $1.51 \pm 0.25^{\mathrm{b}}$ \\
\hline
\end{tabular}

Table 2. Total phenolic contents (grams of gallic acid. $\mathrm{kg}^{-1} \mathrm{FM}$ ), antioxidant capacity (grams of ascorbic acid. $\mathrm{kg}^{-1} \mathrm{FM}$ ), total flavonoid content (grams of rutin. $\mathrm{kg}^{-1} \mathrm{FM}$ ) and ascorbic acid content (grams of ascorbic acid. $\mathrm{kg}^{-1} \mathrm{FM}$ ) of fruits of particular rowanberry cultivars, $\mathrm{n}=10$.

Note: Different superscripts in each column indicate the significant differences in the mean at $P<0.05$.

\begin{tabular}{c|cccc}
\hline Cultivar & Hydroxyl radical (\%) & Superoxide anion (\%) & Nitric oxide (\%) & Lipid peroxidation (\%) \\
\hline \hline Wild rowanberry & $16.33 \pm 0.96^{\mathrm{a}}$ & $26.74 \pm 1.75^{\mathrm{a}}$ & $25.17 \pm 1.72^{\mathrm{a}}$ & $8.21 \pm 0.64^{\mathrm{a}}$ \\
Burka & $20.39 \pm 1.14^{\mathrm{b}}$ & $28.76 \pm 1.23^{\mathrm{a}}$ & $27.53 \pm 1.94^{\mathrm{a}}$ & $10.15 \pm 0.59^{\mathrm{b}}$ \\
Dezertnaya & $19.31 \pm 1.24^{\mathrm{b}}$ & $28.01 \pm 1.58^{\mathrm{a}}$ & $26.04 \pm 1.13^{\mathrm{a}}$ & $10.72 \pm 0.70^{\mathrm{b}}$ \\
Granatina & $24.73 \pm 0.83^{\mathrm{c}}$ & $33.72 \pm 1.11^{\mathrm{b}}$ & $30.88 \pm 1.29^{\mathrm{b}}$ & $13.12 \pm 0.92^{\mathrm{c}}$ \\
Granatnaya & $23.80 \pm 1.04^{\mathrm{c}}$ & $34.02 \pm 1.70^{\mathrm{b}}$ & $31.39 \pm 1.15^{\mathrm{b}}$ & $12.96 \pm 0.67^{\mathrm{c}}$ \\
Likernaya & $16.12 \pm 1.12^{\mathrm{a}}$ & $27.19 \pm 1.37^{\mathrm{a}}$ & $24.75 \pm 1.47^{\mathrm{a}}$ & $7.93 \pm 0.55^{\mathrm{a}}$ \\
Titanovaya & $20.11 \pm 1.46^{\mathrm{b}}$ & $27.38 \pm 1.86^{\mathrm{a}}$ & $25.03 \pm 1.58^{\mathrm{a}}$ & $9.88 \pm 0.69^{\mathrm{b}}$ \\
\hline
\end{tabular}

Table 3. Scavenging effect of rowanberry methanolic extract (10\%) on nitric oxide (percentage of inhibition), superoxide anion (percentage of inhibition), hydroxyl radical (percentage of inhibition) and lipid peroxidation (percentage of inhibition), $\mathrm{n}=10$

Note: Different superscripts in each column indicate the significant differences in the mean at $P<0.05$.

\begin{tabular}{c|cc}
\hline Correlation between & $r^{2}$ & equation \\
\hline \hline TPC and TAC & 0.8904 & $y=1.1859 x+0.8340$ \\
TFC and TAC & 0.8345 & $y=1.8479 x+3.2129$ \\
Ascorbic acid and TAC & 0.9312 & $y=3.7591 x-3.4806$ \\
TPC and hydroxyl radical & 0.8755 & $y=1.5750 x+12.8580$ \\
TFC and hydroxyl radical & 0.8439 & $y=2.4888 x+15.8200$ \\
Ascorbic acid and hydroxyl radical & 0.8930 & $y=4.9299 x+7.4150$ \\
TPC and superoxide anion & 0.8574 & $y=2.0928 x+17.6980$ \\
TFC and superoxide anion & 0.9059 & $y=3.4624 x+20.7460$ \\
Ascorbic acid and superoxide anion & 0.7862 & $y=6.2114 x+12.0240$ \\
TPC and nitric oxide & 0.8959 & $y=1.8499 x+23.0310$ \\
TFC and nitric oxide & 0.8635 & $y=2.9229 x+26.5110$ \\
Ascorbic acid and nitric oxide & 0.9108 & $y=5.7521 x+16.8130$ \\
TPC and lipid peroxidation & 0.9066 & $y=1.0193 x+10.1790$ \\
TFC and lipid peroxidation & 0.9170 & $y=1.6500 x+11.8720$ \\
Ascorbic acid and lipid peroxidation & 0.8580 & $y=3.0734 x+7.1944$
\end{tabular}

Table 4. Correlation relationships between the total phenolic content, the total flavonoid content, the total antioxidant capacity, the ascorbic acid content, and the scavenging effect of rowanberry extracts on hydroxyl radical, nitric oxide, superoxide anion and lipid peroxidation. 


\begin{tabular}{c|ccccc}
\hline Chemical parameter & TAC & Hydroxyl radical & Nitric oxide & Superoxide anion & Lipid peroxidation \\
\hline \hline TPC & $0.8904^{* *}$ & $0.8755^{* *}$ & $0.8574^{* *}$ & $0.8959^{* *}$ & $0.9066^{* *}$ \\
TFC & $0.8345^{* *}$ & $0.8439^{* *}$ & $0.9059^{* *}$ & $0.8635^{* *}$ & $0.9170^{* *}$ \\
AAC & $0.9312^{* *}$ & $0.8930^{* *}$ & $0.7862^{*}$ & $0.9108^{* *}$ & $0.8580^{* *}$ \\
\hline
\end{tabular}

Table 5. Pearson correlation coefficients between investigated chemical parameters. The mean values were used in the analyses of chemical parameters at levels. ${ }^{*} \mathrm{P}<0.05 ;{ }^{*} \mathrm{P}<0.01 ;{ }^{*} * * \mathrm{P}<0.001$

of berries [9]. In assayed cultivars, the highest value of $8.19 \pm 0.56 \mathrm{~g} \mathrm{~kg}^{-1} \mathrm{GAE}$ were found in the Granatnaya rowanberries. The similar value of total polyphenols was noticed by Kampus et al., who reported $4.85 \mathrm{~g} \mathrm{~kg}^{-1} \mathrm{GAE}$ in the Likernaya cultivar [8]. Since the fruit species has not been described in the literature in detail despite its promising properties, one can conclude that it is a matter of cultivars, the influence of the year or the impact of soil or climatic conditions [31-33]. Even this original work supports further research on this fruit species. In relation to polyphenols, flavonoids, a sub-group of polyphenols, are essential chemical compounds with the influence on total antioxidant capacity in wild rowanberries, which also concerns sweet rowanberries [34].

The results obtained point to possibilities of using sweet rowanberries in human nutrition as a good substitute for other wild rowanberries. Moreover, these crosses excel in low requirements for growing conditions and high resistance to frost [3]. Furthermore, their yield is mostly higher in comparison with wild rowanberries. Therefore, these crosses can be grown in Northern European countries (Finland, Sweden) as well as the Siberian regions of Russia and subpolar regions in general [35].

The antioxidant activity is defined as an ability of the compound (or mixture of compounds) to inhibit oxidative reaction of various biomolecules (e.g. to prevent the peroxidation of lipids) [36,37]. Methods of the antioxidant activity determination are usually based on the direct reaction of the studied molecule with radicals (scavenging) or on the reaction with transition metals [38].

When compared with other common fruits species, the AAE values shown in Table 2 suggest that the antioxidant properties of rowanberry cultivars fruits investigated are obvious [20]. For example, in apples the average value of antioxidant capacity is $2.50 \mathrm{~g}$ of AAE $\mathrm{kg}^{-1} \mathrm{FM}$, in pears it is on average $1.90 \mathrm{~g}$ of AAE kg-1 FM. Similarly, cherries reach $1 \mathrm{~g}$ of AAE kg-1 FM [39] and plums have around $5 \mathrm{~g}$ of AAE kg-1 FM [40]. Regarding sweet rowanberries, in our study the values ranged from $6.58 \mathrm{~g}$ of $\mathrm{AAE} \mathrm{kg}{ }^{-1} \mathrm{FM}$ (the cultivar 'Likernaya') to $9.62 \mathrm{~g}$ of $\mathrm{AAE} \mathrm{kg}^{-1} \mathrm{FM}$ (the cultivar 'Granatina'). This is in conflict with analyses done by Kampus et al. (2009) who determined the highest value of antioxidant capacity in the Likernaya cultivar at $11.2 \mathrm{~g}$ of AAE kg-1 FM [8]. As mentioned above, flavonoids are of great significance, particularly anthocyanins and flavonols in aglycone and glycosidic forms [16] as well as conjugated hydrocinnamic acid [41]. Mattila et al. (2006) report that phenolic acids are to a large extent responsible for antioxidant efficiency of sweet rowanberry fruits [35]. In our study, the total flavonoid contents in sweet rowanberry cultivars ranged between $3.37 \mathrm{~g}$ of rutin $\mathrm{kg}^{-1} \mathrm{FM}$ (the cultivar 'Likernaya') and $5.65 \mathrm{~g}$ of rutin $\mathrm{kg}^{-1} \mathrm{FM}$ (the cultivar 'Granatina'). On the other hand, Samec et al. (2009) found the highest content of flavonoids $(7.87 \pm 0.25 \mathrm{mg}$ of CE g-1 FW) in the Likernaya cultivar [42]. In wild rowanberry fruits, the analyses showed the content of $3.11 \mathrm{~g}$ of rutin $\mathrm{kg}^{-1} \mathrm{FM}$. On the whole, it is possible to state that these high flavonoid contents are remarkable and they are mostly two times higher than those found in common species of pomaceous and stone fruit [39]. They can be compared to very rich sources of flavonoids such as sea buckthorn (Hippophae rhamnoides L.) [43] or blue honeysuckle (Lonicera caerulea L. var. kamtchatica (Sevast.) Pojark.) [44,45]. Moreover, Kylli et al. (2010) draw attention to the high flavonoid content in sweet rowanberries [16].

Regarding ascorbic acid, its contents in both wild and sweet rowanberries are known. Nevertheless, the novelty of this work consists in comparing its levels in particular cultivars. In the fruits of wild rowanberries, the content was $0.1 \mathrm{~g} \mathrm{~kg}^{-1} \mathrm{FM}$ on average [39]. On the contrary, sweet rowanberries can reach the values of $4.85 \mathrm{~g} \mathrm{~kg}^{-1} \mathrm{FM}$, particularly in crosses with black chokeberries [8]. In our study, the values ranged from 1.19 to $2.18 \mathrm{~g}$ of ascorbic acid $\mathrm{kg}^{-1} \mathrm{FM}$ (see Table 2). For example, in apples, plums or blackcurrants the average contents of this vitamin are approximately $0.36 \mathrm{~g} \mathrm{~kg}^{-1} \mathrm{FM}, 0.23 \mathrm{~g} \mathrm{~kg}^{-1} \mathrm{FM}$ and $3.25 \mathrm{~g} \mathrm{~kg}^{-1} \mathrm{FM}$, respectively, and mainly blackcurrant is considered to be one of the most valuable sources of ascorbic acid for humans. In addition, kiwi fruits or oranges are known as fruits with high contents of vitamin C (1.00 - $2.95 \mathrm{~g} \mathrm{~kg}^{-1}$ FM). Concerning vegetables, green peppers are one of the richest sources of ascorbic acid; they contain ca. $3.98 \mathrm{~g} \mathrm{~kg}^{-1} \mathrm{FM}$ [39]. In the species studied, ascorbic acid 
level was - similarly to flavonoids and total phenolics highly correlated with antioxidant effects of rowanberry fruit (Table 4). The correlations existing between both the total contents of phenolics, ascorbic acid, flavonoids and antioxidant capacity and scavenging effect on ROS and lipid peroxidation are given in Table 5. Correlation between ascorbic acid and TAC is strongly positive $\left(r^{2}=0.9312\right)$, which does not correspond to findings of Kampuss et al. (2009).

As mentioned by many authors $[1,46,47]$ this is a typical trait of the majority of fruit species not only in the case of antioxidant capacity of phenolics, ascorbic acid, but also where it concerns the relationship between phenolics and ascorbic acid and ROS [48,49].

Besides the new data mentioned above, the major, the novel contribution of this work lies in presentation of analyses of sweet rowanberries scavenging activities against ROS and RNS. As the results suggest, sweet rowanberries are interesting nontraditional fruit species, whose consumption appears to be beneficial owing to high antioxidant efficiency of the fruits. The sweet rowanberry fruit extracts $(10 \%)$ showed moderate inhibitory ability on hydroxyl radical (16.12-24.73\%), superoxide anion (26.74-34.02\%), nitric oxide (24.75$31.39 \%$ ), and lipid peroxidation (7.93-13.12\%). Using extracts of sweet rowanberry fruit was more effective than in other fruit species, e.g. mulberry [50] or apples [51]. In the case of apples, Rop et al. (2011) studied

\section{References}

[1] Tetera V., Fruit of the White Carpathians [Ovoce Bilych Karpat], CSOP, Veseli nad Moravou, Czech Republic, 2006, pp. 66-110

[2] Rop O., Mlcek J., Reznicek V., Mineral elements in fruits interspecific hybrids crane [Mineralni prvky $v$ plodech mezidruhovych krizencu jerabu], Zahradnictvi, 2011, 52, 15-17

[3] Hricovsky I., Small fruit [Drobne ovoce], Priroda, Bratislava, Slovak Republic, 2002, pp. 73-74

[4] Kyzlink V., Principles of Food Preservation, Elsevier, Amsterdam, Netherlands, 1990, pp. 4651

[5] Berna E., Kampuse S., Dukalska L., Murniece I., The chemical and physical properties of sweet rowanberries in powder sugar. Foodbalt-2011, Conference Proceedings, 6th Baltic Conference on Food Science and Technology "Innovations for Food Science and Production“, Jelgava, Latvia, May 5-6, 2011, 163-168

[6] Kutina J., Pomologic atlas [Pomologicky atlas], Brazda, Prague, Czech Republic, 1991, pp. 282283 some cultivars and observed the following ranges of inhibition: hydroxyl radical $9.47 \%-18.12 \%$, superoxide anion $17.10 \%-24.99 \%$ and nitric oxide $12.78 \%-21.36 \%$ [52]. A statistically significant correlation between total flavonoid content and antioxidant activity in rowanberries fruit was observed by Kähkönen et al. (2001), which is in accord with our results $\left(r^{2}=0.8345\right)$ [53]. In our study, the strongest correlation was determined between TFC content and lipid peroxidation $\left(r^{2}=0.9170\right)$ and ascorbic acid and nitric oxide $\left(r^{2}=0.9108\right)$ levels. It is possible to conclude that sweet rowanberries may be strong scavengers of free radicals and that they can be considered a promising fruit species in human nutrition.

Sweet rowanberries are exceptionally valuable fruit species due to the high polyphenolic content. In particular, the high flavonoid content is remarkable. Together with ascorbic acid, these compounds participate in high antioxidant capacity and efficiency against ROS and RNS. Therefore, the consumption of this fruit may work as a prevention of many diseases. Our work provides mostly new data, particularly with regard to comparing the cultivars mutually as well as new results of inhibition efficiency of sweet rowanberries against ROS and RNS. Moreover, this work supports popularization of this nontraditional fruit species and it also aims at stimulation of interest in its cultivation and consumption, which can play important role in the regions with cold climate, hard frost and worse soil conditions.

[7] Janick J., Paull R.E., The Encyclopedia of Fruit and Nuts, CAB International, Cambridge, MA, USA, 2008, $320 p$

[8] Kampuss K., Kampuse S., Berna E., Kruma Z., Krasnova I., et al., Biochemical composition and antiradical activity of rowanberry (Sorbus L.) cultivars and hybrids with different Rosaceae L. cultivars, Latvian Journal of Agronomy, 2008, 1, 59-65.

[9] Hukkanen A.T., Polonen S.S., Karenlampi S.O., Kokko H.I., Antioxidant capacity and phenolic content of sweet rowanberries, J. Agric. Food Chem., 2006, 54, 112-119

[10] Gil-Izquerdo A., Mellethin A., Identification and quantifitation of flavonols in rowanberry (Sorbus aucuparia L.) juice, Eur. Food Res. Technol., 2001, 213, 12-17

[11] Aruoma O.I., Nutrition and health aspects of free radicals and antioxidants, Food Chem. Toxicol., 1994, 62, 671-683

[12] Jomova K., Valko M., Advancases in metal-induced oxidative stress and human disease, Toxicology, $2011,283,65-87$ 
[13] Velisek J., Chemie potravin, OSSIS, Tabor, Czech Republic, 2002, pp. 216-220

[14] Barros L., Falcao S., Baptista P., Freire C., VilasBoas M., Ferreira I.C.F.R., Antioxidant activity of Agaricus spp. mushrooms by chemical, biochemical and electrochemical assays, Food Chem., 2008, 111, 61-66

[15] Wang Z., Hsu Ch., Yin M., Antioxidative characteristics of aqueous and ethanol extracts of glossy privat fruit, Food Chem., 2009, 112, 914918

[16] Kylli P., Nohynek L., Puupponen-Pimiä, R., Westerlund-Wikström B., McDougall G., Stewart $D$, et al., Rowanberry phenolics: Compositional analysis and bioactives, J. Agric. Food Chem., 2010, 58, 11985-11992

[17] Anonymous, UKZUZ - Data from Central Institute for Supervising and Testing in Agriculture, UKZUZ, Brno, Czech Republic, 2008

[18] Barros L., Baptista, P., Ferreira I.C.F.R., Effect of Lactarius piperatus fruiting body maturity stage on antioxidant activity measured by several biochemical assays, Food Chem. Toxicol., 2007, 45, 1731-1737

[19] Kim D.O., Neony S.W., Lee C.Y., Antioxidant capacity of phenolic phytochemicals from various cultivars of plums, Food Chem., 2003, 51, 321-326

[20] Thaipong K., Boonprakob U., Crosby K., CisnerosZevallos L., Byrne D.H., Comparison of ABTS, DPPH, FRAP, and ORAC assays for estimating antioxidant activity from guava fruit extracts, J. Food Compos. Anal., 2006, 19, 669-675

[21] Rupasinghe V.H.P., Jayasankar S., Lay W., Variation in total phenolic and antioxidant capacity among European plum genotypes, Sci. Hortic., 2006, 108, 243-246

[22] Singleton V.L., Orthofer R., Lamuela-Raventos R.M., Analysis of total phenols and other oxidation substrates and antioxidants by Folin-Ciocalteu reagent, Method. Enzymol., 1999, 299, 152-178

[23] Miki N., High-performance liquid-chromatographic determination of ascorbic acid in tomato products, J. Jpn. Soc. Food Sci., 1981, 28, 264-268

[24] Ghiselli A., Nardini M., Baldi A., Scaccini C., Antioxidant activity of different phenolic fractions separated from an Italian red wine, J. Agr. Food Chem., 1998, 46, 361-367.

[25] Beissenhirtz M.K., Kwan R.C., Ko K.M., Renneberg R., Schiller F.W., Liskat F., Comparing an in vitro electrochemical measurement of superoxide scavenging activity with an in vivo assessment of antioxidant potential in Chinese tonifying herbs, Phytother. Res., 2004, 18, 149-153
[26] Green L.C., Wagner D.A., Glogowski J., Skipper P.L., Wishnok, J.S., Tannenbaum, S.R., Analysis of nitrate, nitrite, and $\left[{ }^{15} \mathrm{~N}\right]$ nitrate in biological fluids, Anal. Biochem., 1982, 126, 131-138

[27] Anup S., Shereen R.H., Shivanandappa T., Antioxidant activity of the roots of Decalepis hamiltonii, LWT-Food Sci. Technol., 2006, 36, 1059-1065

[28] Rop O., Mlcek J., Jurikova T., Valsikova M., Antioxidant properties of interspecific crosses of rowan (Sorbus L.). Sborník z mezinárodní vědecké konference „Horticulture Nitra 2012“, SPU Nitra, 13. - 14. 11. 2012, s. 193-197

[29] Mikulic-Petkovsek M., Slatnar A., Stampar F., Veberic R., HPLC-MSn identification and quantification of flavonol glycosides in 28 wild and cultivated berry species, Food Chem. 2012, 135, 2138-2146

[30] Bravo L., Polyphenols: chemistry, dietary sources, metabolim, and nutritional signifikace, Nutr. Rev., 1998, 56, 317-333

[31] Dixon R.A., Paiva N.L., Stress induced phenylpropanoid metabolism, Plant Cell, 1995, 7, 1085-1097

[32] Häkkinen S.H., Kärenlampi S.O., Heinonen I.M., Mykkänen H.M., Törrönen A.R., HPLC method for screening of flavonoids and phenolic acids in berries, J. Sci. Food Agr., 1998, 77, 543-551

[33] Heinonen I.M., Meyer A.S., Frankel E.N., Antioxidant activity of berry phenolics on human low-density lipoprotein nad liposome oxidation, J. Agric. Food Chem., 1998, 46, 4107-4112

[34] Häkkinen S.H., Kärenlampi S.O., Heinonen I.M., Mykkänen H.M., Törrönen A.R., Content of flavonols quercetin, myrycetin and kaempferol in 25 edible berries, J. Agric. Food Chem., 1999, 47, 2274-2279

[35] Mattila P., Hellström J., Törrönen R., Phenolic acids in berries, fruits, and beverages, J. Agric. Food Chem., 2006, 54, 7193-7199

[36] Jurikova T., Sochor J., Rop O., Mlcek J., Balla S., Szekeres L., et al., Polyphenolic Profile and Biological Activity of Chinese Hawthorn (Crataegus pinnatifida BUNGE) Fruits, Molecules, 2012, 17, 14490-14509

[37] Rop O., Reznicek V., Mlcek J., Jurikova T., Sochor J., Kizek R., et al., Nutritional values of new Czech cultivars of Saskatoon berries (Amelanchier alnifolia Nutt.), Hort. Sci., 2012, 39, 123-128

[38] Rop O., Sochor J., Jurikova T., Zitka O., Skutkova H., Mlcek J., Salas P., Krska B., Babula P., Adam V., Kramarova D., Beklova M., Provaznik I., Kizek R. Effect of Five Different Stages of Ripening 
on Chemical Compounds in Medlar (Mespilus germanica L.), Molecules, 2011, 16, 74-91

[39] Kovacikova E., Vojtassakova A., Holcikova K., Simonova E., Food table, [Potravinove tabulky] NOI-UVTIP, Bratislava, Slovak Republic, 1997, pp. 89-90

[40] Rop O., Jurikova T., Mlcek J., Kramarova D., Zultsetseg S., Antioxidant activity and selected nutritional values of plums (Prunus domestica L.) typical of the White Carpathian Mountains, Sci. Hortic-Amsterdam, 2009, 122, 545-549

[41] Määttä-Riihinen K.R., Kamal-Eldin A., Mattila P.H., Gonzales-Paramas A.M., Törrönen A.R., Distribution and contents of phenolic compounds in eighteen Scandinavian berry species, J. Agric. Food Chem., 2004, 52, 4477-4486

[42] Samec D., Salopek I., Salopek-Sondi B., Piljac Žegarac J., Grafting black chokeberry (Aronia melanocarpa L., var. Viking) onto European rowan (Sorbus aucuparia L.) yields fruit with superior phytochemical content and bioactivity In: International Symposium of Biotech StudentsBook of AbstractsZagreb: Students' Association of Biotechnology Helix, 2009, 31-32

[43] Sabir S.M., Maqsood H., Hayat M., Khan M.Q., Khaliq A., Elemental and nutritional analysis of sea buckthorn (Hippophae rhamnoides ssp. turkestanica) berries of Pakistani origin, J. Med. Food, 2005, 8, 518-522

[44] Rop O., Řezníček V., Mlček J., Juríková T., Balík J., Sochor J., et al., Antioxidant and radical oxygen species scavenging activities of 12 cultivars of blue honeysuckle fruit, Hort. Sci., 2011, 38, 63-70

[45] Jurikova T., Sochor J., Rop O., Mlcek J., Balla S., Szekeres L., et al., Evaluation of polyphenolic profile and nutritional value of non-traditional fruit species in the Czech Republic - a comparative study, Molecules, 2012, 17, 8968-8981

[46] Perino-Issartier S., Zill-e-Huma, Abert-Vian M., Chemat F., Solvent free microwave-assisted extraction of antioxidants from sea buckthorn (Hippophae rhamnoides) food by-products, Food Bioprocess Tech., 2011, 4, 1020-1028

[47] Tiitinen K.M., Yang B.R., Haraldsson G.G., Jonsdottir S., Kallio H.P., Fast analysis of sugars, fruit acids, and vitamin $\mathrm{C}$ in sea buckthorn (Hippophae rhamnoides L.) varieties, J. Agr. Food Chem., 2006, 54, 2508-2513

[48] Rop O., Mlcek J., Jurikova T., Valsikova M., Bioactive content and antioxidant capacity of Cape gooseberry fruit, Cent. Eur. J. Biol., 2012, 7, 672679

[49] Rop O., Posolda M., Mlcek J., Reznicek V., Sochor J., Adam V., Kizek R., Sumczynski D., Qualities of Native Apple Cultivar Juices Characteristic of Central Europe, Not. Bot. Horti Agrobo., 2012, 40, 222-228

[50] Bae S.H., Suh H.J., Antioxidant activities of five different mulberry cultivars in Korea, LWT-Food Sci. Technol., 2007, 40, 955-962

[51] Maffei F., Tarozzi A., Karbone F., Marchesi A., Hrelia S., Angeloni C., et al., Relevance of apple consumption for protection against oxidative damage induced by hydrogen peroxide in human lymphocytes, Brit. J. Nutr., 2007, 97, 921-927

[52] Rop O., Jurikova T., Sochor J., Mlcek J., Kramarova D., Antioxidant capacity, scavenging radical activity and selected chemical composition of native apple cultivars from Central Europe, J. Food Quality, 2011, 34, 187-194

[53] Kähkönen M.P., Hopia A.I., Heinonen M., Berry phenolics and their antioxidant activity, J. Agr. Food Chem., 2001, 49, 4076-4082 